\title{
THE ECOLOGIZATION OF HOUSING AND COMMUNAL SERVICES OF UKRAINE IN THE CONTEXT OF SUSTAINABLE DEVELOPMENT
}

\author{
Iryna Kinash \\ Ivano-Frankivsk National Technical University of Oil and Gas, Ukraine \\ Halyna Shtogryn \\ Institute of Environmental Economics and Sustainable Development of the National \\ Academy of Sciences of Ukraine, Ukraine \\ Oksana Sakal \\ Institute of Environmental Economics and Sustainable Development of the National \\ Academy of Sciences of Ukraine, Ukraine \\ Ivanna Zapukhliak \\ Ivano-Frankivsk National Technical University of Oil and Gas, Ukraine
}

\begin{abstract}
The article presents the results of the research of ecologization of housing and communal services in Ukraine and distinguishes their characteristic features. It develops the method of integrated assessment of the level of ecologization of housing and communal services and calculates it in Ukrainian regions. The concept of ecologization of housing and communal services is formed, which is based on the model of sustainable development. It offers financial and economic instruments for stimulating the development of Ukrainian housing and communal services.
\end{abstract}

Keywords: Sustainable development, Ecologization, Housing and communal services, Ukraine.

DOI: http://dx.doi.org/10.15549/jeecar.v6i1.251

\section{INTRODUCTION}

The modern stage of the economic development of Ukraine is characterized by an increase of negative human impact on the environment. The aggravation of problems is accompanied by environmental constraints of economic growth. It proves the need for Ukraine to move from a technogenic type of economic development to a new direction aimed at achieving sustainable development. As it is known, the Concept of sustainable development has become popular after the publication of the "Our Common Future" report, prepared in 1987 by the UN Commission on Environment and Development under the leadership of the Prime Minister of Norway Gro Harlem Brundtland. The development of economic benefits weakens the problem of sustainable ecologically oriented 
social reproduction. The sustainable development does not destroy its natural basis, spiritual and cultural foundation, and provided standards of living do not lead to large-scale destructive processes that threaten the existence of this society (Report, 1987).

The United Nations Conference on Environment and Development, held in Rio de Janeiro (Brazil) in 1992, confirmed and developed the ideas of the Stockholm Conference on the approach to the global environmental crisis (Resolution, 1992). The World Program of Action "Agenda XXI" was adopted at this conference. At the "Agenda XXI" resolution, an estimation of the planetary situation of human development was made. It noted that the contradiction between the formed character of the development of both civilization and nature has reached its peak: the apparent hopelessness of the civilization development model, which was adopted by developing countries; the welfare of the Western powers is based on the irrational exploitation of the natural resources of the planet, overestimated production, and consumption (General, 1992).

The repeated attempts to overcome the crisis in the social, economic and environmental spheres at various levels of socio-ecological and economic systems (global, national, regional and local) were undertaken. This is confirmed by various international events devoted to the achievement of sustainable development. Thus, in 1997, in Kyoto (Japan) an international agreement (Kyoto Protocol) containing specific measures to reduce greenhouse gas emissions was signed. This international agreement was signed by representatives from 38 countries including EU countries.

The Summit 2000 in New York adopted the Millennium Declaration, in which the UN set out the Millennium Development Goals to 2015. They are aimed at: eliminating poverty and hunger; obtaining general secondary education; promoting equality of women and men, women's empowerment, reduction of child mortality; maternity health improvement; fight against HIV/AIDS, malaria, and inhumane diseases; provision of ecologic resistance; and the formation of a global partnership for development (Millennium, 2010).
The International Conference on Financing for Development in Monterrey (Mexico) on March 18-22, 2002 noted the lack of resources and appealed to agreed international development goals, including those ones contained in the Millennium Goals (International, 2002). It is suggested to use such instruments as tax levies, investments in economic and social infrastructure, development of capital markets through banking systems, and conduct fiscal and monetary policies.

At the World Summit on Sustainable Development, the results and achievements in environmental protection were summed up after the conference in Rio de Janeiro. The concept of sustainable development was internationally recognized (Earth, 2002). In September 2015, the United Nations Summit in New York hosted the work of participating countries for the implementation of 17 Development Goals for the period up to 2030 (General, 2015). The uniqueness of the outcome document is that it integrates in a harmonious way three components of sustainable development: economic growth, social wellbeing, and environmental protection.

As the document (General, 1992) defines the responsibility of national governments to develop programs and policies to ensure sustainable development, we note that some steps have been taken in Ukraine. The Law "On the Basic Principles (Strategy) of the State Environmental Policy of Ukraine for the Period up to 2020" (The Law, 2015) and the Strategy for Ukraine 2020 Sustainable Development (Decree, 2015) were adopted. Among the reasons for the environmental problems of Ukraine, insufficient understanding of the priorities of preservation of the environment and the benefits of sustainable development have been identified in the society. In this context, we focus on ecologizing the economy as a necessary condition for Ukraine's transition to a sustainable development model. An ecologic economy requires changes in the priorities and goals of the state's development. We shall note that at the beginning of the XXI century there were clear signs of environmentalization of society in Ukraine. A large number of scientific works devoted to the economy of nature use, sustainable development; environmental risks 
in the economy, and environmental management and audit were published. The institutional support of the ecologization of social development was intensified. Thus, the state strategy of environmental policy determines ways of reducing the negative impact on the natural environment (The Law, 2015):

- reduction of the level of air pollution by stationary sources by $25 \%$ (as compared to 2010) and mobile sources (transition to the Euro-5 standard);

- an increase in the amount of energy produced using renewable and alternative energy sources by $55 \%$;

- -increase the share of public transport in the general structure by $25 \%$;

- raising the indicators of planting green areas of settlements, etc.

Such high projections are due to Ukraine's commitments at the Johannesburg Summit, the Kyoto Protocol and the Millennium Goals.

Ukraine confirmed its desire to implement the principle of sustainable development by joining the international program documents in this area of activity. The target point of the public vision of Ukraine's development until 2030 is the achievement of the welfare of the population, which can be achieved through the ecologization of housing and communal services. Such an approach, in our opinion, will contribute to the life quality improvement of the population without harming the environment.

\section{REVIEW OF LITERATURE}

Research evidence shows that there are different approaches to understanding the essence of sustainable development. Sustainable development is understood by the authors in different ways: harmonious, balanced, nonconflict progress of all earthly civilization, groups of countries (regions, subregions), as well as individual countries of our planet based on scientifically substantiated plans (systematic approach), when in the process of steady innovation intensive (and not extensive) economic development of countries. At the same time, a complex set of questions concerning the preservation of the environment, the elimination of exploitation, poverty, and discrimination of every single person, as well as of whole peoples or groups of people, are solved positively (Herman, 1996). The MerriamWebster Online (2009) defines sustainable development as capable of being sustained. By Meadow's, a sustainable development is meeting or satisfying our current needs and requirements and at the same don't create threats for future generations (Meadows, Randers, Meadows, \& Behrens, 1972).

Constancy as a category also possesses different characteristics. Sustainability means transforming our ways of living to maximize the chances that environmental and social conditions will indefinitely support human security, well-being and health (McMichael, Butler \& Folke, 2003). "I define sustainability as the possibility that all forms of life will flourish forever" (Ehrenfcld, 2005). A central contribution of the Brundtland Report was tying human development and actions to environmental carrying capacities across the generations (Kates, Parris, \& l.eiserowirz, 2005; Khator, \& Fairchild, 2006). Voinov, \& Farley, (2007) expand upon this point, offering examples of sustainable ecological communities in which individual species appear and disappear through succession, and sustainable business economies in which entrepreneurial firms supplant existing organizations relying on outmoded business models. Senge, Smith, Kruschwitz, Laur, \& Schley (2008) focused on the environmental protection. Mandryk, Arkhypova, Pukish, Zelmanovych, \& Yakovlyuk, (2017) developed theoretical and methodological principles of sustainable development of geosystems, proved the scientific direction - ecological safety. Sterman (2012) noted a systematic approach to sustainability. White (2013) generalized the definition of constancy. The result of the study is a visually attractive type of terms, which provides a composite picture of the essence of constancy. He argues that "constancy is determined through environment, economic and social, life, system, nature, resources, human, development, needs, community, produce, time, earth, generation, ecology, world, process, meet, means, people, growth, equity" (p. 216). 
The ecology of housing and communal services will be considered as a model of development that will eliminate ecological and economic contradictions and ensure a harmonious combination of the environment of human life and the quality of the environment. Such development is possible upon the implementation of organizational and economic measures aimed at increasing the efficiency of the use of natural resources.

The concept of sustainable development finds its place not only in various types of human activity, but also in different forms of social organization such as the city (Mesjasz-Lech, 2014) and the village (Ristianti, 2016). Ecologization of housing construction is an evolutionary process in terms of the form of sustainable housing (Joo, \& Wong, 2008). This process requires the involvement of various sources of funding and effective use of funds (Aizinova, 2016). Problems in the functioning of housing and communal services lead to a decrease in the quality of life. The main reason is the inefficient management system (Kolyhaeva, 2015). Ensuring sustainable development of housing and communal services is possible through the use of sustainable management. Kryukova, Povarov, Ruzanova, Ruzanova, \& Frolovskii (2017) emphasize the functions of monitoring the provision of communal services, and Austin, Gurran, \& Whitehead (2014) on differences in planning systems.

Problems of ecologization of housing construction are actively studied by scientists in a number of works, in particular: Joo at al. (2008); Aizinova (2016) offered ways to provide high-quality housing and communal services at the expense of the effectiveness using different sources of funding. Kryukova at al. (2017) studied the issue of payment utilities, and ways to control their provision, taking into account the peculiarities of sustainable management.

The purpose of the article is to present the results of the study on the ecologization of the housing and communal services of Ukraine and to elaborate directions for its revitalization.

\section{METHODOLOGY AND MODEL SPECIFICATION}

Housing and communal services: essence, structure, characterization

Ukraine's transition to a sustainable development model is possible due to the radical structural and techno-technological restructuring of social production, in particular, in the direction of ecologization of the branches of economy and social sphere.

The housing and communal economy of the state is chosen for research. The housing and communal economy of the state is a complex of types of economic activity, providing a housing stock with communal services necessary for the civilized residence of people in it. The investigated sphere is a complex multifunctional economic structure, which has an exceptional social and economic significance.

Let's take into account such characteristic features of housing and communal services as: providing for sanitary, hygienic and safe living conditions of citizens and maintenance of the proper condition of buildings, structures, residential and non-residential premises.

\section{Methodological approach to evaluation}

We consider ecologization of housing and communal entities in a complex way and we believe that it can be generally assessed through indicators of social and environmental development. Thus, we developed our own method of integrated assessment, which envisaged five stages: identification of the components of housing and communal services; definition of boundaries of integral quantities; normalization of indicators; calculation of coefficients for each indicator; calculation and construction of an integrated comparative index of socio-ecological development. The following indicators are selected:

- the provision of housing for population on average per one person, $\mathrm{m}^{2}$ of the total area;

- share of old residential houses in the total number of all residential buildings, \%;

- share of the total area of old residential houses in the total number of area of all dwelling houses, \%;

- share of unfit houses in the total number 
of all residential buildings, \%;

- share of the total area of unfit houses in the total number of area of all residential buildings, \%;

- plumbing facilities, \%

- sewage facilities, \%

- heating facilities, \%

- gas facilities, \%

- hot water supply facilities, \%

- volume of use of fresh water for domestic and drinking needs, million $\mathrm{m}^{3}$;

- use of fresh water for domestic and drinking needs per one person per day;

- volume of discharge of return water in surface water objects, million $\mathrm{m}^{3}$;

- the formation of household and similar wastes, tons;

- the formation of household and similar wastes per capita, kg;

- gross regional product per capita (in actual prices), UAH.

These indicators are available for evaluation and are contained in the statistical reports of the State Statistics Service of Ukraine (State, 2011, 2017).

All of these indicators have positive or negative impact on the ecological and economic development of the territory. Therefore, at the next stage of assessing the level of ecologization of the subjects of the country for each indicator, the reference region, which has the best actual value of the criterion (maximum or minimum), taken per unit, is determined. Next, a comparative analysis is performed on the partial relation of the leading region with others by the following formulas:

$$
I_{n}^{i}=\frac{Y_{n}^{i}}{Y_{\max }^{n}} \quad I_{n}^{i}=\frac{Y_{n}^{i}}{Y_{\min }^{i}}
$$

where $Y_{n}^{i}=$ the value of the $n$-th baseline for the $i$-th region; $Y_{\max }^{n}, Y_{\min }^{i}=$ the best maximum and minimum value of the n-base; $I_{n}^{i}$ = assessment of the level of development of the $i$-th region relative to the leader in the $n$-th indicator.
After that, the average value of the basic indices for each region under study is calculated, resulted in territories ranking by the level of reduction. At the final stage, the interpretation of the received data on the level of ecologization of subjects is carried out, which distinguishes regions with different levels of socio-ecological development, namely, with the index value: from 0,000 to 0,200 - very low; from 0,201 to 0,400 - low; from 0,401 to 0,600 average; from 0,601 to 0,800 - higher than average; from 0,801 to 1,000 - high level.

\section{INTEGRATED ASSESSMENT RESULTS}

The results of calculations are presented in Table 1.

On the basis of the calculated integral indicator of the social and ecological development of housing and communal services, it can be stated that generally in Ukraine it is average (its value ranges from 0,496 to 0,529 ). Most Ukrainian regions possess low level of ecologization of housing and communal services. The highest level of ecologization was achieved in Odesa and Kharkiv regions and in the Kyiv city. This is due to the following reasons: inefficient management of housing and communal services enterprises; insufficient level of housing provision and communal services; an ineffective business mechanism characterized by a departmental monopoly, costly nature, unreasonable tariff policy, and lack of incentives to improve performance. 
Table 1. Results of the integrated assessment of socio-ecological development of housing and communal services in Ukraine and its regions

\begin{tabular}{|c|c|c|c|c|c|c|c|}
\hline \multirow[t]{3}{*}{ Region } & \multicolumn{4}{|c|}{ Integral index } & \multirow{2}{*}{\multicolumn{3}{|c|}{$\begin{array}{l}\text { The level of social and } \\
\text { environmental development of } \\
\text { housing and communal services }\end{array}$}} \\
\hline & \multicolumn{2}{|c|}{2010} & \multicolumn{2}{|l|}{2016} & & & \\
\hline & value & rating & value & rating & 2010 & 2016 & $\begin{array}{l}\text { Change the } \\
\text { index, } \pm\end{array}$ \\
\hline Ukraine & 0,496 & - & 0,529 & - & average & average & $-0,033$ \\
\hline Crimea & 0,281 & 15 & $*_{-}$ & ${ }^{*}-$ & low & $*_{-}$ & ${ }^{*}-$ \\
\hline Vinnytsia & 0,310 & 10 & 0,301 & 14 & low & low & 0,009 \\
\hline Volyn region & 0,244 & 23 & 0,257 & 19 & low & low & $-0,013$ \\
\hline Dniprovska & 0,383 & 6 & 0,436 & 5 & low & average & $-0,095$ \\
\hline Donetsk & 0,440 & 3 & 0,440 & 4 & average & average & 0,000 \\
\hline Zhytomyr & 0,265 & 19 & 0,289 & 16 & low & low & $-0,024$ \\
\hline Transcarpathian & 0,249 & 21 & 0,269 & 18 & low & low & $-0,020$ \\
\hline Zaporizhia & 0,299 & 12 & 0,334 & 12 & low & low & $-0,035$ \\
\hline Ivano-Frankivsk & 0,211 & 25 & 0,255 & 20 & low & low & $-0,044$ \\
\hline Kyiv & 0,336 & 8 & 0,395 & 6 & low & low & $-0,059$ \\
\hline Kirovohrad & 0,159 & 27 & 0,159 & 25 & very low & very low & 0,000 \\
\hline Luhansk & 0,249 & 22 & 0,200 & 24 & low & very low & 0,049 \\
\hline Lviv & 0,273 & 16 & 0,324 & 13 & low & low & $-0,051$ \\
\hline Mykolayiv & 0,308 & 11 & 0,298 & 15 & low & low & $-0,010$ \\
\hline Odesa & 0,442 & 2 & 0,448 & 3 & average & average & $-0,006$ \\
\hline Poltava & 0,297 & 14 & 0,361 & 9 & low & low & $-0,064$ \\
\hline Rivne & 0,250 & 20 & 0,269 & 17 & low & low & $-0,019$ \\
\hline Sumy & 0,297 & 13 & 0,368 & 8 & low & low & $-0,071$ \\
\hline Ternopil & 0,264 & 19 & 0,351 & 11 & low & low & $-0,087$ \\
\hline Kharkiv & 0,439 & 4 & 0,492 & 2 & average & average & $-0,053$ \\
\hline Kherson & 0,328 & 9 & 0,356 & 10 & low & low & $-0,028$ \\
\hline Khmelnytsky & 0,235 & 24 & 0,242 & 21 & low & low & $-0,007$ \\
\hline Cherkasy & 0,359 & 7 & 0,368 & 7 & low & low & $-0,009$ \\
\hline Chernivtsi & 0,270 & 17 & 0,239 & 22 & low & low & 0,031 \\
\hline Chernihiv & 0,178 & 26 & 0,209 & 23 & very low & low & $-0,031$ \\
\hline City of Kyiv & 0,512 & 1 & 0,515 & 1 & average & average & $-0,003$ \\
\hline City of Sevastopol & 0,432 & 5 & $*_{-}$ & $*_{-}$ & average & $*_{-}$ & $*_{-}$ \\
\hline
\end{tabular}

* - no data available.

THE CONCEPT OF ENVIRONMENTALIZATION OF HOUSING AND COMMUNAL SERVICES AND THE CONDITIONS FOR ITS IMPLEMENTATION

In our opinion, the main direction of ecologization of housing and communal services is to improve functioning of the housing and utilities sector due to efficient use of resources, reduction of pollution and domestic waste, introduction of innovative energy-efficient and energy-saving technologies. The authors propose the concept of ecologization of housing and communal services, based on the sustainable development model (Fig. 1).

The advisability of the proposed concept stems from the fact that: first, the branch is socially oriented, since its main purpose is to provide the human with the necessary living conditions; and secondly, the economic activity of housing and communal enterprises creates a heavy load on the environment; and thirdly, the industry is financially unstable. 


\section{Economic component:}

- branch output to international standards for providing energy-saving services; rational use of a housing stock;

- interaction with international organizations in the field of world technologies, technological equipment of the industry in compliance with environmental safety requirements;

- attraction of foreign investors for realization of investment projects on construction and reconstruction of residential buildings, development of social infrastructure of settlements, engineering infrastructure by increasing the ecological image of enterprises and organizations of housing and communal services;

- increase of investments in the development of social infrastructure and environmental protection activities;

- $\quad$ optimization of the structure of enterprise management in accordance with the requirements of sustainable development.

\section{Ecological component:}

- proper water supply, drainage, waste management;

- organization and introduction into the administrative structure of the ecological subdivisions;

- improvement of personnel qualification in the field of environmental protection and rational use of natural resources;

- formation of ecological consciousness of workers by providing reference information, instructions and educational materials;

- Implementation of resource-saving and energy-efficient technologies.

\section{4}

\section{Ecologization of development of} housing and communal services

Fig. 1. Conceptual bases of ecologization of development of housing and communal services

The main conditions for the implementation of the concept should be:

- $\quad$-improvement of the regulatory framework in the sphere of housing and communal services;
- -availability and completeness of information about the ecological condition and landscaping of territories; 
- $\quad$-effectiveness of incentive mechanisms implementation of environmental programs and measures by enterprises;

- $\quad$ preparation of specialists for solving the problems of negative environmental impact of housing and communal enterprises;

- -accumulation of financial resources for the implementation of environmental programs, etc.

Since the ecologization of housing and communal services depends to a large extent on the activities of the construction industry, we propose measures that are environmentally oriented, namely:

- conducting an environmental audit of the crisis areas of Ukraine, which provides for the definition of control levels of pollution of territories, which are norms for territories for the next 1-3 years, and the possibility of their real achievement, the primary conducting of eco-audits in highly urbanized areas and cities;

- $\cdot$ development of urban-planning measures aimed at the withdrawal of territories from the crisis;

- $\quad$ development and implementation of programs for the creation and production of new resource-saving building materials and constructions;

- -development of integrated programs for the implementation of non-waste and environmentally sound technologies;

- $\cdot d e v e l o p m e n t$ and introduction of mobile, light, environmentally safe and low-energy construction machinery and mechanized instrument;

- -development and implementation of architectural and planning measures, measures on the protection of individual objects, measures on reorienting the infrastructure of the territories.

\section{FINANCIAL AND ECONOMIC INSTRUMENTS FOR ENVIRONMENTAL DEVELOPMENT OF HOUSING AND COMMUNAL SERVICES}

Implementation of the conceptual provisions of sustainable ecological and economic development is possible through creation and providing incentive measures that will promote compliance with environmental and economic interests in the housing and communal sector. We offer the following financial and economic instruments for stimulating the development of housing and communal services of the state.

Payments for the pollution of the environment by the subjects of the housing and communal services should be charged for: emissions into the air of pollutants; emission of pollutants in surface and underground water objects; placement of solid domestic waste and consumption; other negative impacts on the environment.

Crediting. Budgetary funds of various levels are an attractive financial source, but as an investment resource, they are limited. For the use of energy saving equipment by actors and the technological re-equipment of outdated fixed assets, significant financial investments are required (for the restoration of heating networks, energy efficiency improvement of the housing stock, etc.).

Amortization policy. Depreciation of fixed assets is a universal mechanism for stimulating the activities of community-based organizations world-wide recognized, as its accrual creates an important source of investment financing for enterprises interested in further growth, modernization and technical re-equipment. A sufficient measure in foreign countries to promote priority activities and scientific and technological progress in the area of providing utilities is accelerated depreciation of fixed assets, which is to increase amortization deductions in the first years of equipment operation. As a result, such an economic tool, such as accelerated depreciation, is interested in updating facilities in a shorter period of their payback. Increased depreciation due to the cost of production reduces the taxable base of 
income tax and increases the investment opportunities of enterprises for the purchase of environmental protection and environmental equipment. The introduction and use of accelerated depreciation in the countries of the world contributed to accelerating the attraction of capital to replace obsolete technologies and switching to resource-saving equipment, which minimizes damage to the natural environment. In relation to treatment facilities, housing and environmental equipment, such a procedure is not provided for in the current domestic legislation, which impedes the modernization of facilities and dramatically impairs the availability of enterprises with existing facilities.

Buying and selling of rights to environmental pollution (from the sphere of housing and communal services), which may become one of the promising economic instruments of ecologization of activity in Ukraine. In the European Union, in order to stimulate the reduction of the negative impact on the environment, the trade in permits for polluting emissions (emissions) - sale of unrealized part of emission allowances within the limits set. Enterprises that pollute the environment operate within the limits of total installed emission limit values in the region. Trade in emission permits within the region is permitted provided that the specified emission limit in this territory is observed. If a subject allocates less than the size of the contamination set for him, he may sell to another enterprise or exchange (on a commercial basis) the difference (lack of) emissions. In Ukraine, this practice is not yet implemented.

\section{CONCLUSION}

Nowadays, ecologization is understood as the process of gradual and consistent implementation of systems of technological, managerial and other decisions, which allow to increase the efficiency of the use of natural resources and conditions along with improving or preserving the quality of the natural environment.

So, ecologization of housing and communal services development is a process of consistent implementation of administrative, technological and managerial measures, incentives and instruments in its activity, which provide rational nature management, minimization of its impact on the environment, and high living standards of the population. We believe that this approach should become a priority in ensuring sustainable development of the state.

Proposed own methodology for assessing the social and environmental development of housing and communal services, based on which is the calculation of the integral index of the level of its ecologization. On the basis of the calculated indicator, we state that in most regions of Ukraine its level is low, although in general in Ukraine it is an average.

In order to improve the situation, the concept of ecologization of housing and communal services based on the model of sustainable development has been put forward. The feasibility of the proposed concept stems from the following provisions: the industry is socially oriented and financially unstable, and the economic activity poses a big burden on the environment. Within the framework of the proposed concept, financial and economic instruments for stimulating the ecologization of housing and communal services are considered, among which are identified: payments for pollution of the environment by subjects of the investigated sphere, lending, amortization policy, sale and purchase of rights to environmental pollution associated with its activities.

\section{REFERENCE}

AACSB International. (Sept.2017). The Association to Advance Collegiate Schools of Business: Eligibility Procedures and Accreditation Standards for Business Accreditation.

ACTE. (2010). Association for Career and Technical Education. What is Career Ready? Alexandra, VA: Available: http://dpi.wi.gove/oea/pdf/crpaper.pdf

ATC21S. (2010). Assessment and Teaching of 21st Century Skills Project. http://atc21s.org/index.php/resources/white papers/\# item 1.

Ananiadou, K. and Claro, M. (2009). 21st century skills and competences for new millennium learners in OECD countries. Paris: Organization for Economic Cooperation and Development. Available: http://www.oecd- 
ilibrary.org/education/21st-century-skills

Bath, D., Smith, C., Stein, S. \& Swann, R. (2004). Beyond mapping and embedding graduate attributes: bringing together quality assurance and action learning to create a validated

and living curriculum. Higher Education Research \& Development, 23(3), 313-328.

Binkley, M., Erstad, O., Herman, J., Raizen, S., Ripley, M., and Rumble, M. (2010). Defining 21st Century Skills. White Paper commissioned for the National Research Council. (2012). Education

Conley, D. T. (2007). Redefining College Readiness. Eugene, OR: Educational Policy Improvement Center (EPIC). https://www.epiconline.org/files/pdf/Redefi ningCollegeReadiness.

Davies, A., Fidler, D., \& Gorbis, M. (n.d.). Future Work Skills 2020. IFTF: The Institute for the Future.www.iftf.org Institute for the Future for the University of Phoenix Research Institute.

De La Harpe, B., Radloff, A., \& Wyber, J. (2000). Quality and generic (professional) skills. Quality in Higher Education, 6(3), 231-243.

Emberg, S, \& Benson, L. (2010). Integrating Professional skills into a Bachelor of commerce program: A case study. In Proceedings of $17^{\text {th }}$ EDiNEB Conference (June 09-12), London, United Kingdom.

EFMD (EPAS). (2017). European Foundation for Management Development.

Finegold, D., and Notabartolo, A.S. (2010). 21st Century Competencies and their Impact: An Interdisciplinary Literature Review. Paper commissioned for the NRC Project on Research on 21st Century Competencies: A Planning Process on Behalf of the Hewlett Foundation.http://www7.nationalacademies .org/bota/Finegold_Notabartolo_Impact_Pap er.pdf.

Jackson, D. \& Chapman, E. (2012). Non-technical competencies in undergraduate business degree programs: Australian and UK perspectives. Studies in Higher Education, 37(5), 541-567.

Jackson, D. \& Chapman, E. (2012). Non-technical competencies in undergraduate business degree programs: Australian and UK perspectives. Studies in Higher Education, 37(5), 541-567.

National Research Council. (2012). Education for Life and Work: Developing Transferable Knowledge and Skills in the 21st Century. Committee on Defining Deeper Learning and 21st Century Skills, James W. Pellegrino and Margaret L. Hilton, Editors. Board on Testing and Assessment and Board on Science Education, Division of Behavioral and Social Sciences and Education. Washington, DC: The National Academies Press.

Robley, W., Whittle, S., \& Murdoch-Eaton, D. (2005). Mapping generic skills curricula: Outcomes and discussion. Journal of further and Higher Education, 29(4), 321-330.

Salas, E., Bedwell, W.L., and Fiore, S.M. (2011). Developing the 21st Century (and Beyond)

Workforce: A Review of Interpersonal Skills and Measurement St Aizinova, I. M. (2016). Stud. Russ. Econ. Dev. 27: 453. https://doi.org/10.1134/S107570071604002X

Austin, PM, Gurran, N. \& Whitehead, CME J. (2014). Hous and the Built Environ. 29: 455. https://doi.org/10.1007/s10901-0139356-3

Decree of the President of Ukraine on the Strategy for Sustainable Development "Ukraine 2020": No. 5/2015 dated January 12, 2015. Retrieved from http://www.president.gov.ua/documents/18 688.html

Earth Summit (2002). Building Partnerships for Sustainable Development. Retrieved from https://www.earthsummit2002.org/

Ehrenfeld. J.R. (2005). The roots of sustainability. MIT Sloan Management, Review 46 (2), 2325.

General Assembly Resolution (1992). Programme for the Further Implementation of Agenda 21, / RES / S-19/2. Retrieved from http://www.un-documents.net/s19r2.htm

General Assembly Resolution (2015). 17 Goals to Transform Our World : New York, NY, USA, 25-27 September. Retrieved from https://www.un.org/sustainabledevelopment

Herman, D. (1996). Beyond growth: the economics of sustainable development. Beacon Press, 253 
International Conference on Financing and Development Monterrey (2002). Mexico, March 18-22. Retrieved from https://www.imf.org/external/np/pdr/FfD/2 0021

Joo, T.T.K. \& Wong, TC. (2008) Public Housing in Singapore: A Sustainable Housing Form and Development. Springer. Retrieved from https://doi.org/10.1007/978-1-4020-65422_8

Kates, R. W., Parris, T. M. \& l.eiserowirz, A. A. (2005). What is sustainable development? Environment, 47(3), 8-21.

Khalor, R. \& Fairchild. L. (2006). The evolution of "Sustainable development". Globalization and Sustainable Development: Issues and Applications, 13-22. Retrieved from http://www.patelcenter.usf.edu,/globalizati on_sustainable_development.php

Kolyhaeva, Y. (2015). The Development of Information Technologies in the Sphere of Housing Service and Utilities as a Factor of National Life Quality Increase. Procedia Social and Behavioral Sciences, Volume 166, 557-561. Retrieved from https://doi.org/10.1016/j.sbspro.2014.12.572

Kryukova, E. S., Povarov, I. S., Ruzanova, E. V., Ruzanova, V. D. \& Frolovskii, N. G. (2017, May 17). Issues of Effectiveness of Communal Service in View of Variability of Apartment Blocks Management System. Russia and the European Union, 9-16. Retrieved from https://link.springer.com/content/pdf/bfm\% 3A978-3-319-55257-6\%2F1.pdf

Mandryk, O., Arkhypova, L., Pukish, A., Zelmanovych, A. \& Yakovlyuk, Kh. (2017). Theoretical and methodological foundations of sustainable development of Geosystems. IOP Publishing. IOP Conf. Series: Materials Science and Engineering, Volume 200. Retrieved from http://iopscience.iop.org/issue/1757899X/200/1

McMichael, A. J., Butler, C. D. \& Folke, C. (2003). New visions for addressing sustainability. Science, 302, 1919-1920.

Meadows, D. H. Randers, J., Meadows, D. L. \& Behrens, W. W. (1972). The Limits to Growth: A Report for the Club of Rome's Project on the Predicament of
Mankind. 1. Universe Books, 211. (Original work written in USA)

Merriam-Webster Online, (2009). Sustainability. Merriam-Webster: online dictionary. Retrieved from http://www.merriamwebster.com/dictionary/sustainability

Mesjasz-Lech, A. (2014). Municipal Waste Management in Context of Sustainable Urban Development. Procedia - Social and Behavioral Sciences, Volume 151, 244-256. Retrieved from https://doi.org/10.1016/j.sbspro.2014.10.023

Millennium Development Goals (2010, September 20-22). UN Summit: New York. Retrieved from www. un.org/en/mdg/summit2010/

Report of the World Commission on Environment and Development (1987, December 11). Our Common Future, General Assembly Resolution 42/187: New York, NY, USA. Retrieved from http://www.un.org/documents/ga/res/42/ar es42-187.htm

Resolution 1, Annex II (1992). Rio Declaration on Environment and Development, A/CONF.151/26. Retrieved from http://www.un-documents.net/riodec.htm

Ristianti, S. (2016). S.M.A.R.T. Eco-village for Hazardous Coastal Area in Bedono Village. Procedia - Social and Behavioral Sciences, Volume 227, 593-600

Senge, P., Smith, B., Kruschwitz N., Laur, J. \& Schley, S.(2008). The Necessary Revolution: How Individuals and Organizations are Working Together to Create a Sustainable World. Doubleday, New York. (Original work written in USA)

State Committee of Statistics of Ukraine (2017). Regions of Ukraine in 2017, 2 volumes, Retrieved from www.ukrstat.gov.ua

Sterman. J. D. (2012). Sustaining sustainability: creating a systems science in a fragmented academy and polarized world. Sustainability Science: The Emerging Paradigm and the Urban Environment Springer. New York, pp.21-58

On the Basic Principles (Strategy) of the State Environmental Policy of Ukraine for the Period until 2020. The Law of Ukraine. Retrieved from 
http://zakon.rada.gov.ua/laws/show/ru/281 8-17

Voinov. A. \& Farley. J. (2007). Reconciling sustainability, systems theory and discounting. Ecological Economics, 63 (1), 104-113

White, M. (2013). Sustainability: I know it when I see it. Ecological Economics, Volume 86, February. 213-217. Retrieved from https://doi.org/10.1016/j.ecolecon.2012.12.0 20

rategies. Paper prepared for the NRC Workshop on Assessing 21st Century Skills. Available: http://www7.nationalacademies.org/bota/2 1st_Century_Workshop_Salas_Fiore_Paper.p df.

Sumsion, J. \& Goodfellow, J. (2004). Identifying generic skills through curriculum mapping: a critical evaluation. Higher Education Research \& Development, 23(3), 329-346.

Voogt, J., and Pareja Roblin, N. (2010). 21st Century Skills Discussion Paper. Report prepared for Kennisnet University of Twente.

\section{ABOUT THE AUTHORS}

Iryna Kinash, email: irinakinash@gmail.com.

Dr. Iryna Kinash is a Professor at Department of Management and Administration, Ivano-Frankivsk National Technical University of Oil and Gas, Ukraine. Her research is aimed at ensuring the sustainable development of the social sphere of the state. Dr. Kinash has published about 100 works, most of which are in domestic editions. She works in international journals: Actual Problems of Economics (Scopus); International Journal of Advanced Scientific Research, Sustainable Economic Development, Financial Space, etc. He is a member of the editorial board of the Scientific Bulletin of the Ivano-Frankivsk National Technical University of Oil and Gas (series "Economics and Management").

Ms. Halyna Shtohryn works as researcher at the Public Institution "Institute of Environmental Economics and Sustainable
Development of the National Academy of Sciences of Ukraine». She is the Candidate of Sciences. Her scientific research is devoted to the scientific substantiation of economic and ecological instruments for the development of housing and communal services and the social sphere. Halyna has published more than 25 scientific papers in Ukrainian and foreign publications, of which more than 9 articles in the journals indexed in science-based databases of Spatial Economics.

Ms. Oksana Sakal works as the Senior Researcher at the Institute of Environmental Economics and Sustainable Development of the National Academy of Sciences of Ukraine». She is the Candidate of Sciences in Economics. Her scientific research is devoted to the scientific substantiation of economic instruments for the sustainable use of natural resources. Ms. Sakal published over 135 scientific papers, of which more than 40 articles in the journals indexed in science-based databases AURA, Spatial Economics, Economics of APS, Economist, etc. She is a member of the editorial board of the scientific journal "Environmental Economics and Sustainable Development."

Dr. Ivanna Zapukhliak is a Professor at Department of Management and Administration, Ivano-Frankivsk National Technical University of Oil and Gas, Ukraine. Her scientific interests include energy saving policy, energy saving potential of gas transportation companies of Ukraine, development of the enterprise in the conditions of instability, ecological and economic aspects of the development of gas transportation enterprises. Dr. Zapukhliak has published more than 70 works, most of which are in domestic editions. She is on editorial boards of various international journals of Economic Processes Management, Prospects of Economic Development in the Global Crisis, and Economic magazine-XXI (Scopus). 


\section{Annex A.1}

Socio-ecological indicators of definition of sustainable development of housing and communal services of Ukraine, 2010

\begin{tabular}{|c|c|c|c|c|c|c|c|c|c|c|c|c|c|c|c|c|}
\hline \multirow[t]{2}{*}{ Region } & \multicolumn{16}{|c|}{ Number Indicator } \\
\hline & 1 & 2 & 3 & 4 & 5 & 6 & 7 & 8 & 9 & 10 & 11 & 12 & 13 & 14 & 15 & 16 \\
\hline Ukraine & 23,3 & 0,5 & 0,4 & 0,1 & 0,1 & 58,9 & 56,8 & 61,3 & 83,9 & 43,4 & 1917 & 42 & 7817 & 11352544,81 & 4032,45 & 23600 \\
\hline Crimea & 19,7 & 0,2 & 0,2 & 0,1 & 0,2 & 76,3 & 72,3 & 65,6 & 1,9 & 58,4 & 109 & 55 & 202 & 376688,92 & 5212,56 & 16507 \\
\hline Vinnytsia & 26,7 & 0,6 & 0,4 & 0,2 & 0,2 & 31,8 & 30,6 & 38,8 & 84,3 & 17,4 & 33 & 20 & 69 & 110030,85 & 14915,83 & 14332 \\
\hline Volyn & 20,5 & 0,5 & 0,3 & 0,1 & 0,1 & 49,0 & 46,9 & 48,0 & 80,0 & 33,3 & 24 & 23 & 46 & 114668,11 & 9044,79 & 13916 \\
\hline Dnipropetrovsk & 23,3 & 0,3 & 0,4 & 0,1 & 0,1 & 68,7 & 65,8 & 72,3 & 89,7 & 47,1 & 243 & 73 & 1176 & 1085121,91 & 3074,77 & 34709 \\
\hline Donetsk & 22,7 & 0,7 & 0,6 & 0,3 & 0,2 & 70,3 & 68,3 & 63,2 & 65,3 & 43,4 & 231 & 52 & 1503 & 2011899,62 & 2203,40 & 28986 \\
\hline Zhytomyr & 24,6 & 0,7 & 0,6 & 0,1 & 0,1 & 35,8 & 35,4 & 40,5 & 84,1 & 27,2 & 27 & 21 & 151 & 159232,48 & 8032,33 & 14606 \\
\hline Zakarpattia & 22,6 & 0,2 & 0,4 & 0,1 & 0 & 63,1 & 62,0 & 50,6 & 79,6 & 27,3 & 14 & 11 & 41 & 108576,61 & 11488,20 & 12278 \\
\hline Zaporizhia & 22,4 & 0,2 & 0,2 & 0,1 & 0 & 64,6 & 62,8 & 63,8 & 88,2 & 57,8 & 106 & 59 & 838 & 462783,12 & 3892,35 & 23657 \\
\hline Ivano-Frankivsk & 23,6 & 0,3 & 0,2 & 0,1 & 0,1 & 39,3 & 38,6 & 40,5 & 87,0 & 33,2 & 19 & 14 & 91 & 168592,11 & 8184,05 & 14814 \\
\hline Kyiv & 31,6 & 0,4 & 0,2 & 0,1 & 0,1 & 52,8 & 51,2 & 81,7 & 95,4 & 35,6 & 46 & 27 & 810 & 891627,36 & 1926,42 & 26140 \\
\hline Kirovohrad & 24,5 & 0 & 0,1 & 0 & 0 & 43,3 & 42,5 & 49,6 & 91,5 & 31,5 & 23 & 23 & 41 & 196660,67 & 5135,68 & 15533 \\
\hline Luhansk & 23,8 & 0,4 & 0,4 & 0 & 0,1 & 59,3 & 57,9 & 55,5 & 60,8 & 33,6 & 79 & 34 & 321 & 851464,67 & 2690,98 & 19788 \\
\hline Lviv & 21,2 & 0,3 & 0,2 & 0,1 & 0,1 & 60,9 & 59,8 & 49,2 & 89,3 & 49,5 & 78 & 31 & 230 & 372602,28 & 6829,66 & 16353 \\
\hline Mykolaiiv & 21,7 & 0,4 & 0,3 & 0,2 & 0,1 & 58,0 & 55,0 & 62,9 & 89,7 & 51,2 & 49 & 41 & 88 & 506208,82 & 2337,54 & 20276 \\
\hline Odesa & 22,2 & 1,0 & 0,7 & 0,2 & 0,3 & 65,3 & 60,2 & 54,4 & 87,8 & 41,2 & 119 & 50 & 292 & 439328,01 & 5437,10 & 22544 \\
\hline Poltava & 24,7 & 0,4 & 0,3 & 0,1 & 0,1 & 48,2 & 46,9 & 59,6 & 90,6 & 38,4 & 53 & 35 & 183 & 241003,99 & 6173,14 & 29652 \\
\hline
\end{tabular}


(Annex A.1. Continue)

\begin{tabular}{|l|l|l|l|l|l|l|l|l|l|l|l|l|l|l|l|l|}
\hline Rivne & 21,1 & 0,5 & 0,3 & 0,1 & 0,1 & 45,0 & 43,6 & 49,0 & 72,5 & 29,4 & 24 & 21 & 110 & 90517,43 & 12732,64 & 13785 \\
\hline Sumy & 23,1 & 0,8 & 0,4 & 0,1 & 0,1 & 46,1 & 44,2 & 62,8 & 89,9 & 31,8 & 32 & 27 & 57 & 159430,69 & 7285,57 & 15711 \\
\hline Ternopil & 22,9 & 0,3 & 0,2 & 0,2 & 0,1 & 46,6 & 41,5 & 56,7 & 92,9 & 34,5 & 16 & 15 & 62 & 110984,81 & 9768,25 & 11713 \\
\hline Kharkiv & 22,9 & 0,9 & 0,9 & 0,1 & 0,1 & 67,1 & 66,2 & 81,3 & 89,6 & 60 & 143 & 52 & 298 & 806483,42 & 3416,20 & 23639 \\
\hline Kherson & 23,5 & 0,3 & 0,2 & 0,1 & 0,1 & 68,9 & 58,9 & 56,6 & 93,1 & 41,4 & 40 & 37 & 78 & 78280,37 & 13901,79 & 14346 \\
\hline Khmelnytsk & 25 & 0,5 & 0,3 & 0,1 & 0,1 & 37,4 & 35,6 & 49,7 & 91,4 & 27,4 & 33 & 25 & 50 & 263844,72 & 5029,19 & 13602 \\
\hline Cherkasy & 26,2 & 0,8 & 0,6 & 0,2 & 0,2 & 41,7 & 41,1 & 55,9 & 92,5 & 29 & 34 & 26 & 207 & 175577,27 & 7320,90 & 17325 \\
\hline Chernivtsi & 22,6 & 0,3 & 0,2 & 0,3 & 0,2 & 35,2 & 35,0 & 38,8 & 89,5 & 27,2 & 10 & 11 & 50 & 73182,88 & 12356,40 & 10939 \\
\hline Chernihiv & 25,5 & 0,3 & 0,2 & 0 & 0 & 36,4 & 34,3 & 45,6 & 83,3 & 28,9 & 31 & 28 & 119 & 156871,14 & 7000,71 & 15406 \\
\hline Kyiv (city) & 21 & 0,6 & 0,1 & 0 & 0 & 99,0 & 99,0 & 99,4 & 74,1 & 97,7 & 274 & 98 & 650 & 346156,25 & 8086,52 & 70424 \\
\hline Sevastopol (city) & 22 & 0,3 & 0,1 & 0,1 & 0,2 & 96,8 & 88,8 & 86,8 & 94,6 & 80,1 & 27 & 71 & 54 & 90002,92 & 4231,21 & 20455 \\
\hline
\end{tabular}

(Annex A.1 To continue)

\section{Annex A.2}

Comparative analysis of social and environmental indicators of sustainable development of housing and communal services with the region-leader, 2016

\begin{tabular}{|c|c|c|c|c|c|c|c|c|c|c|c|c|c|c|c|c|c|c|}
\hline \multirow[t]{2}{*}{ Region } & \multicolumn{18}{|c|}{ Number Indicator } \\
\hline & 1 & 2 & 3 & 4 & 5 & 6 & 7 & 8 & 9 & 10 & 11 & 12 & 13 & 14 & 15 & 16 & Total & Total to 16 \\
\hline Ukraine & 0,303 & 0,500 & 0,375 & 0,333 & 0,333 & 0,403 & 0,383 & 0,371 & 0,877 & 0,324 & 1,000 & 0,356 & 1,000 & 1,000 & 0,162 & 0,213 & 7,934 & 0,496 \\
\hline Crimea & 0,000 & 0,200 & 0,125 & 0,333 & 0,667 & 0,662 & 0,610 & 0,442 & 0,000 & 0,511 & 0,052 & 0,506 & 0,021 & 0,027 & 0,253 & 0,094 & 4,502 & 0,281 \\
\hline Vinnytsia & 0,588 & 0,600 & 0,375 & 0,667 & 0,667 & 0,000 & 0,000 & 0,000 & 0,881 & 0,000 & 0,012 & 0,103 & 0,004 & 0,003 & 1,0 & 0,057 & 4,957 & 0,310 \\
\hline Volyn & 0,067 & 0,500 & 0,250 & 0,333 & 0,333 & 0,256 & 0,238 & 0,152 & 0,835 & 0,198 & 0,007 & 0,138 & 0,001 & 0,004 & 0,548 & 0,050 & 3,911 & 0,244 \\
\hline Dnipropetrovsk & 0,303 & 0,300 & 0,375 & 0,333 & 0,333 & 0,549 & 0,515 & 0,553 & 0,939 & 0,370 & 0,122 & 0,713 & 0,146 & 0,090 & 0,088 & 0,400 & 6,128 & 0,383 \\
\hline
\end{tabular}


(Annex A.2. Continue)

\begin{tabular}{|c|c|c|c|c|c|c|c|c|c|c|c|c|c|c|c|c|c|c|}
\hline Donetsk & 0,252 & 0,700 & 0,625 & 1,0 & 0,667 & 0,573 & 0,551 & 0,403 & 0,678 & 0,324 & 0,116 & 0,471 & 0,188 & 0,172 & 0,021 & 0,303 & 7,044 & 0,440 \\
\hline Zhytomyr & 0,412 & 0,700 & 0,625 & 0,333 & 0,333 & 0,060 & 0,070 & 0,028 & 0,879 & 0,122 & 0,009 & 0,115 & 0,014 & 0,008 & 0,470 & 0,062 & 4,240 & 0,265 \\
\hline Zakarpattia & 0,244 & 0,200 & 0,375 & 0,333 & 0,000 & 0,466 & 0,459 & 0,195 & 0,831 & 0,123 & 0,002 & 0,000 & 0,000 & 0,003 & 0,736 & 0,023 & 3,990 & 0,249 \\
\hline Zaporizhia & 0,227 & 0,200 & 0,125 & 0,333 & 0,000 & 0,488 & 0,471 & 0,413 & 0,923 & 0,503 & 0,050 & 0,552 & 0,102 & 0,035 & 0,151 & 0,214 & 4,787 & 0,299 \\
\hline Ivano-Frankivsk & 0,328 & 0,300 & 0,125 & 0,333 & 0,333 & 0,112 & 0,117 & 0,028 & 0,910 & 0,197 & 0,005 & 0,034 & 0,006 & 0,008 & 0,482 & 0,065 & 3,384 & 0,211 \\
\hline Kyiv & 1,0 & 0,400 & 0,125 & 0,333 & 0,333 & 0,313 & 0,301 & 0,708 & 1,0 & 0,227 & 0,019 & 0,184 & 0,099 & 0,073 & 0,000 & 0,256 & 5,370 & 0,336 \\
\hline Kirovohrad & 0,403 & 0,000 & 0,000 & 0,000 & 0,000 & 0,171 & 0,174 & 0,178 & 0,958 & 0,176 & 0,007 & 0,138 & 0,000 & 0,011 & 0,247 & 0,077 & 2,541 & 0,159 \\
\hline Luhansk & 0,345 & 0,400 & 0,375 & 0,000 & 0,333 & 0,409 & 0,399 & 0,276 & 0,630 & 0,202 & 0,036 & 0,264 & 0,036 & 0,069 & 0,059 & 0,149 & 3,982 & 0,249 \\
\hline Lviv & 0,126 & 0,300 & 0,125 & 0,333 & 0,333 & 0,433 & 0,427 & 0,172 & 0,935 & 0,400 & 0,036 & 0,230 & 0,024 & 0,027 & 0,377 & 0,091 & 4,369 & 0,273 \\
\hline Mykolaiiv & 0,168 & 0,400 & 0,250 & 0,667 & 0,333 & 0,390 & 0,357 & 0,398 & 0,939 & 0,421 & 0,020 & 0,345 & 0,006 & 0,038 & 0,032 & 0,157 & 4,921 & 0,308 \\
\hline Odesa & 0,210 & 1,0 & 0,750 & 0,667 & 1,0 & 0,499 & 0,433 & 0,257 & 0,919 & 0,296 & 0,057 & 0,448 & 0,032 & 0,032 & 0,270 & 0,195 & 7,066 & 0,442 \\
\hline Poltava & 0,420 & 0,400 & 0,250 & 0,333 & 0,333 & 0,244 & 0,238 & 0,343 & 0,949 & 0,262 & 0,023 & 0,276 & 0,018 & 0,015 & 0,327 & 0,315 & 4,746 & 0,297 \\
\hline Rivne & 0,118 & 0,500 & 0,250 & 0,333 & 0,333 & 0,196 & 0,190 & 0,168 & 0,755 & 0,149 & 0,007 & 0,115 & 0,009 & 0,002 & 0,832 & 0,048 & 4,006 & 0,250 \\
\hline Sumy & 0,286 & 0,800 & 0,375 & 0,333 & 0,333 & 0,213 & 0,199 & 0,396 & 0,941 & 0,179 & 0,012 & 0,184 & 0,002 & 0,008 & 0,413 & 0,080 & 4,754 & 0,297 \\
\hline Ternopil & 0,269 & 0,300 & 0,125 & 0,667 & 0,333 & 0,220 & 0,159 & 0,295 & 0,973 & 0,213 & 0,003 & 0,046 & 0,003 & 0,003 & 0,604 & 0,013 & 4,227 & 0,264 \\
\hline Kharkiv & 0,269 & 0,900 & 1,0 & 0,333 & 0,333 & 0,525 & 0,520 & 0,701 & 0,938 & 0,531 & 0,070 & 0,471 & 0,033 & 0,065 & 0,115 & 0,213 & 7,018 & 0,439 \\
\hline Kherson & 0,319 & 0,300 & 0,125 & 0,333 & 0,333 & 0,552 & 0,414 & 0,294 & 0,975 & 0,299 & 0,016 & 0,299 & 0,005 & 0,000 & 0,922 & 0,057 & 5,244 & 0,328 \\
\hline Khmelnytsk & 0,445 & 0,500 & 0,250 & 0,333 & 0,333 & 0,083 & 0,073 & 0,180 & 0,957 & 0,125 & 0,012 & 0,161 & 0,001 & 0,017 & 0,239 & 0,045 & 3,755 & 0,235 \\
\hline Cherkasy & 0,546 & 0,800 & 0,625 & 0,667 & 0,667 & 0,147 & 0,154 & 0,282 & 0,969 & 0,144 & 0,013 & 0,172 & 0,021 & 0,009 & 0,415 & 0,107 & 5,739 & 0,359 \\
\hline Chernivtsi & 0,244 & 0,300 & 0,125 & 1,000 & 0,667 & 0,051 & 0,064 & 0,000 & 0,937 & 0,122 & 0,000 & 0,000 & 0,001 & 0,000 & 0,803 & 0,000 & 4,313 & 0,270 \\
\hline Kyiv (city) & 0,109 & 0,600 & 0,000 & 0,000 & 0,000 & 1,0 & 1,0 & 1,0 & 0,772 & 1,0 & 0,138 & 1,0 & 0,078 & 0,024 & 0,474 & 1,0 & 8,197 & 0,512 \\
\hline
\end{tabular}




\section{Annex B.1}

Socio-ecological indicators of definition of sustainable development of housing and communal services of Ukraine, 2010

\begin{tabular}{|c|c|c|c|c|c|c|c|c|c|c|c|c|c|c|c|c|}
\hline \multirow[t]{2}{*}{ Region } & \multicolumn{16}{|c|}{ Number Indicator } \\
\hline & 1 & 2 & 3 & 4 & 5 & 6 & 7 & 8 & 9 & 10 & 11 & 12 & 13 & 14 & 15 & 16 \\
\hline Ukraine & 22,5 & 0,5 & 0,4 & 0,1 & 0,1 & 59,7 & 56,6 & 67,5 & 85,2 & 46,6 & 1500 & 35 & 6354 & 10747973 & 3994,2 & 33057 \\
\hline Crimea & 28,7 & 0,7 & 0,4 & 0,2 & 0,1 & 39,9 & 38,2 & 50,8 & 83,4 & 24,4 & 31 & 19 & 70 & 209784,7 & 7677,3 & 24224 \\
\hline Vinnytsia & 22,1 & 0,4 & 0,3 & 0,1 & 0 & 54,9 & 52,9 & 57,3 & 78,7 & 39,5 & 23 & 22 & 44 & 118556,9 & 8796,8 & 19694 \\
\hline Volyn & 24,1 & 0,3 & 0,4 & 0,1 & 0,1 & 69,5 & 66,6 & 75,7 & 89,5 & 48,1 & 224 & 68 & 1123 & 1206409 & 2716 & 43632 \\
\hline Dnipropetrovsk & 11,8 & 0,7 & 0,5 & 0,3 & 0,2 & 70,2 & 68,4 & 65 & 66,4 & 49,1 & 158 & 37 & 914 & 498450,4 & 8621,2 & 26942 \\
\hline Donetsk & 26,7 & 0,7 & 0,6 & 0,1 & 0,1 & 38,9 & 38,5 & 49 & 84,8 & 30 & 25 & 20 & 159 & 196555,6 & 6389,9 & 19646 \\
\hline Zhytomyr & 24 & 0,1 & 0,1 & 0 & 0 & 72,7 & 72,2 & 69,5 & 83,9 & 56,6 & 14 & 11 & 31 & 172211,1 & 7314,1 & 16633 \\
\hline Zakarpattia & 23,2 & 0,2 & 0,2 & 0,1 & 0 & 65,5 & 64 & 67 & 88,4 & 59,2 & 88 & 50 & 807 & 444315 & 3974,5 & 30101 \\
\hline Zaporizhia & 25,2 & 0,3 & 0,2 & 0,1 & 0,1 & 44,3 & 44 & 63,4 & 87,9 & 38,2 & 19 & 14 & 73 & 270342 & 5114,1 & 21970 \\
\hline Ivano-Frankivsk & 34,2 & 0,5 & 0,2 & 0,1 & 0,1 & 59,5 & 57,9 & 88 & 94,2 & 46,5 & 45 & 26 & 724 & 778842,7 & 2220,3 & 38905 \\
\hline Kyiv & 25,2 & 0 & 0,1 & 0 & 0 & 45,2 & 44,3 & 52 & 91,1 & 32,6 & 19 & 19 & 90 & 300274,2 & 3265,6 & 24730 \\
\hline Kirovohrad & 8 & 0,3 & 0,4 & 0 & 0,1 & 55,6 & 54,7 & 56,9 & 70,6 & 38,9 & 28 & 13 & 53 & 293989,9 & 7551,8 & 12312 \\
\hline Luhansk & 22,6 & 0,2 & 0,1 & 0,1 & 0,1 & 66,5 & 65,7 & 62,4 & 89 & 56,6 & 62 & 24 & 215 & 5474622,2 & 463,56 & 24605 \\
\hline Lviv & 22,2 & 0,2 & 0,2 & 0,1 & 0,1 & 59,5 & 56,5 & 65,1 & 89,3 & 51,9 & 36 & 31 & 125 & 524883,5 & 2218,3 & 25721 \\
\hline Mykolaiiv & 22,3 & 0,7 & 0,7 & 0,2 & 0,2 & 68,2 & 61,2 & 56,7 & 85,8 & 43,6 & 107 & 45 & 206 & 719587,5 & 3330,3 & 29517 \\
\hline Odesa & 25,1 & 0,5 & 0,4 & 0,2 & 0,1 & 48,8 & 47,3 & 69,5 & 90 & 38,7 & 49 & 34 & 194 & 296673,3 & 4884,1 & 37000 \\
\hline Poltava & 21,7 & 0,6 & 0,4 & 0,1 & 0,1 & 49,4 & 48,3 & 59,1 & 72 & 34,5 & 23 & 20 & 112 & 161565,5 & 7186,9 & 19102 \\
\hline Rivne & 25 & 0,9 & 0,5 & 0,2 & 0,1 & 48,1 & 46,1 & 66,9 & 87,8 & 34,2 & 32 & 28 & 49 & 208314,9 & 5393 & 22609 \\
\hline
\end{tabular}


(Annex B.1. Continue)

\begin{tabular}{|l|l|l|l|l|l|l|l|l|l|l|l|l|l|l|l|l|}
\hline Sumy & 24,8 & 0,3 & 0,2 & 0,2 & 0,1 & 52,5 & 48,5 & 74,9 & 94 & 40,4 & 15 & 14 & 70 & 97377,1 & 10988 & 17849 \\
\hline Ternopil & 23,9 & 0,8 & 0,8 & 0,1 & 0,1 & 68 & 67,1 & 84,9 & 89,3 & 60,6 & 145 & 53 & 299 & 950107,6 & 2874,7 & 30799 \\
\hline Kharkiv & 23,8 & 0,3 & 0,2 & 0,1 & 0,1 & 68,5 & 59,3 & 55,7 & 92,4 & 40,7 & 45 & 42 & 56 & 109573,6 & 9745,7 & 18572 \\
\hline Kherson & 25,9 & 0,5 & 0,3 & 0,1 & 0 & 40,8 & 39,6 & 62,6 & 91,5 & 30,8 & 29 & 22 & 29 & 311626,6 & 4175,6 & 21852 \\
\hline Khmelnytsk & 27,4 & 0,7 & 0,5 & 0,2 & 0,2 & 43,6 & 42,8 & 58,9 & 90,3 & 31,9 & 31 & 25 & 165 & 287764,6 & 4350,1 & 24449 \\
\hline Cherkasy & 23,6 & 0,1 & 0,1 & 0,2 & 0,2 & 41,4 & 41,1 & 52,3 & 90,8 & 35,3 & 11 & 12 & 61 & 442988 & 2054,2 & 14604 \\
\hline Chernivtsi & 28,2 & 0,4 & 0,3 & 0,1 & 0 & 40,2 & 37,7 & 53,1 & 83,2 & 31,6 & 30 & 28 & 101 & 305720,8 & 3453,1 & 22132 \\
\hline Chernihiv & 21,7 & 0,7 & 0,1 & 0,1 & 0 & 98,7 & 80,2 & 99,1 & 69,2 & 95,3 & 211 & 73 & 584 & 1294596,3 & 2230,8 & 109308 \\
\hline Kyiv (city) & 23,2 & 0,2 & 0,2 & 0,1 & 0 & 65,5 & 64 & 67 & 88,4 & 59,2 & 88 & 50 & 807 & 444315 & 3974,5 & 30101 \\
\hline Sevastopol (city) & 25,2 & 0,3 & 0,2 & 0,1 & 0,1 & 44,3 & 44 & 63,4 & 87,9 & 38,2 & 19 & 14 & 73 & 270342 & 5114,1 & 21970 \\
\hline
\end{tabular}

\section{Annex B.2}

Comparative analysis of social and environmental indicators of sustainable development of housing and communal services with the regionleader, 2016

\begin{tabular}{|c|c|c|c|c|c|c|c|c|c|c|c|c|c|c|c|c|c|c|}
\hline \multirow[t]{2}{*}{ Region } & \multicolumn{18}{|c|}{ Number Indicator } \\
\hline & 1 & 2 & 3 & 4 & 5 & 6 & 7 & 8 & 9 & 10 & 11 & 12 & 13 & 14 & 15 & 16 & Total & Total 16 \\
\hline Ukraine & 0,553 & 0,556 & 0,429 & 0,333 & 0,500 & 0,348 & 0,445 & 0,369 & 0,676 & 0,313 & 1,0 & 0,387 & 1,0 & 1,0 & 0,335 & 0,214 & 8,459 & 0,529 \\
\hline Crimea & 0,790 & 0,778 & 0,429 & 0,667 & 0,500 & 0,017 & 0,012 & 0,036 & 0,612 & 0,000 & 0,013 & 0,129 & 0,011 & 0,011 & 0,685 & 0,123 & 4,811 & 0,301 \\
\hline Vinnytsia & 0,538 & 0,444 & 0,286 & 0,333 & 0,000 & 0,268 & 0,358 & 0,166 & 0,442 & 0,213 & 0,008 & 0,177 & 0,007 & 0,002 & 0,792 & 0,076 & 4,110 & 0,257 \\
\hline Volyn & 0,615 & 0,333 & 0,429 & 0,333 & 0,500 & 0,512 & 0,680 & 0,533 & 0,831 & 0,334 & 0,143 & 0,919 & 0,177 & 0,104 & 0,214 & 0,323 & 6,980 & 0,436 \\
\hline Dnipropetrovsk & 0,145 & 0,778 & 0,571 & 1,0 & 1,0 & 0,523 & 0,722 & 0,319 & 0,000 & 0,348 & 0,099 & 0,419 & 0,144 & 0,038 & 0,775 & 0,151 & 7,033 & 0,440 \\
\hline
\end{tabular}


(Annex B.2. Continue)

\begin{tabular}{|c|c|c|c|c|c|c|c|c|c|c|c|c|c|c|c|c|c|c|}
\hline Donetsk & 0,714 & 0,778 & 0,714 & 0,333 & 0,500 & 0,000 & 0,019 & 0,000 & 0,662 & 0,079 & 0,009 & 0,145 & 0,025 & 0,009 & 0,563 & 0,076 & 4,626 & 0,289 \\
\hline Zhyto & 611 & 111 & 0,000 & 0,000 & 0,000 & 0,565 & 0,812 & 0,409 & 0,629 & 0,454 & 0,002 & 0,000 & 0,005 & 0,007 & 0,651 & 0,045 & 4,301 & 0,269 \\
\hline Zakarpattia & 580 & 222 & 143 & ,333 & 0,000 & 0,445 & 0,619 & 0,359 & 0,791 & 0,491 & 0,052 & 0,629 & 0,127 & 0,033 & 0,334 & 0,183 & 5,341 & 0,334 \\
\hline Zaporizhia & 656 & 0,333 & 0,143 & 0,333 & 0,500 & 0,090 & 0,148 & 0,287 & 0,773 & 0,195 & 0,005 & 0,048 & 0,011 & 0,016 & 0,442 & 0,100 & 4,083 & 0,255 \\
\hline Ivano-Frankivsk & 1,0 & 0,556 & 0,143 & 0,333 & 0,500 & 0,344 & 0,475 & 0,778 & 1,0 & 0,312 & 0,023 & 0,242 & 0,114 & 0,064 & 0,167 & 0,274 & 6,325 & 0,395 \\
\hline Kyiv & 0,656 & 0,000 & 0,000 & 0,000 & 0,000 & 0,105 & 0,155 & 0,060 & 0,888 & 0,116 & 0,005 & 0,129 & 0,014 & 0,019 & 0,266 & 0,128 & 2,543 & 0,159 \\
\hline Kirovohrad & 0,000 & 0,333 & 0,429 & 0,000 & 0,500 & 0,279 & 0,400 & 0,158 & 0,151 & 0,205 & 0,011 & 0,032 & 0,008 & 0,018 & 0,674 & 0,000 & 3,198 & 0,200 \\
\hline Luhansk & 0,557 & 0,222 & 0,000 & 0,333 & 0,500 & 0,462 & 0,659 & 0,267 & 0,813 & 0,454 & 0,034 & 0,210 & 0,034 & 0,505 & 0,000 & 0,127 & 5,177 & 0,324 \\
\hline Lviv & 0,542 & 0,222 & 0,143 & 0,333 & 0,500 & 0,344 & 0,442 & 0,321 & 0,824 & 0,388 & 0,017 & 0,323 & 0,020 & 0,040 & 0,167 & 0,138 & 4,764 & 0,298 \\
\hline Mykolaiiv & 0,546 & 0,778 & 0,857 & 0,667 & 1,0 & 0,490 & 0,553 & 0,154 & 0,698 & 0,271 & 0,064 & 0,548 & 0,032 & 0,058 & 0,272 & 0,177 & 7,166 & 0,448 \\
\hline Odesa & 0,653 & 0,556 & 0,429 & 0,667 & 0,500 & 0,166 & 0,226 & 0,409 & 0,849 & 0,202 & 0,026 & 0,371 & 0,031 & 0,019 & 0,420 & 0,255 & 5,775 & 0,361 \\
\hline Poltava & 0,523 & 0,667 & 0,429 & 0,333 & 0,500 & 0,176 & 0,249 & 0,202 & 0,201 & 0,142 & 0,008 & 0,145 & 0,018 & 0,006 & 0,639 & 0,070 & 4,308 & 0,269 \\
\hline Rivne & 0,649 & 1,000 & 0,571 & 0,667 & 0,500 & 0,154 & 0,198 & 0,357 & 0,770 & 0,138 & 0,014 & 0,274 & 0,008 & 0,010 & 0,468 & 0,106 & 5,885 & 0,368 \\
\hline Sumy & 0,641 & 0,333 & 0,143 & 0,667 & 0,500 & 0,227 & 0,254 & 0,517 & 0,993 & 0,226 & 0,003 & 0,048 & 0,011 & 0,000 & 1,000 & 0,057 & 5,620 & 0,351 \\
\hline Ternopil & 0,607 & 0,889 & 1,0 & 0,333 & 0,500 & 0,487 & 0,692 & 0,717 & 0,824 & 0,511 & 0,090 & 0,677 & 0,047 & 0,080 & 0,229 & 0,191 & 7,873 & 0,492 \\
\hline Kharkiv & 0,603 & 0,333 & 0,143 & 0,333 & 0,500 & 0,495 & 0,508 & 0,134 & 0,935 & 0,230 & 0,023 & 0,500 & 0,009 & 0,001 & 0,882 & 0,065 & 5,694 & 0,356 \\
\hline Kherson & 0,683 & 0,556 & 0,286 & 0,333 & 0,000 & 0,032 & 0,045 & 0,271 & 0,903 & 0,090 & 0,012 & 0,177 & 0,005 & 0,020 & 0,353 & 0,098 & 3,864 & 0,242 \\
\hline Khmelnytsk & 0,740 & 0,778 & 0,571 & 0,667 & 1,000 & 0,079 & 0,120 & 0,198 & 0,860 & 0,106 & 0,013 & 0,226 & 0,026 & 0,018 & 0,369 & 0,125 & 5,896 & 0,368 \\
\hline Cherkasy & 0,595 & 0,111 & 0,000 & 0,667 & 1,0 & 0,042 & 0,080 & 0,066 & 0,878 & 0,154 & 0,000 & 0,016 & 0,010 & 0,032 & 0,151 & 0,024 & 3,825 & 0,239 \\
\hline Chernivtsi & 0,771 & 0,444 & 0,286 & 0,333 & 0,000 & 0,022 & 0,000 & 0,082 & 0,604 & 0,102 & 0,013 & 0,274 & 0,016 & 0,020 & 0,284 & 0,101 & 3,352 & 0,209 \\
\hline Chernihiv & 0,523 & 0,778 & 0,000 & 0,333 & 0,000 & 1,0 & 1,0 & 1,0 & 0,101 & 1,0 & 0,134 & 1,0 & 0,092 & 0,112 & 0,168 & 1,0 & 8,241 & 0,515 \\
\hline Kyiv (city) & 0,553 & 0,556 & 0,429 & 0,333 & 0,500 & 0,348 & 0,445 & 0,369 & 0,676 & 0,313 & 1,0 & 0,387 & 1,0 & 1,0 & 0,335 & 0,214 & 8,459 & 0,529 \\
\hline
\end{tabular}

